Research Article

\title{
The Structure and Nature of Political Philosophy in the Thought of Muslim Philosophers of the Islamic Period of Iran
}

\section{Aref Barkhordari*}

Assistant Professor Department of Political Thought. University of Tehran, Iran

Article Information
Received: 15 September 2020
Revised version received: 16 October 2020
Accepted: 19 October 2020
Published: 29 October 2020
Cite this article as:
A. Barkhordari (2020) Int. J. Soc. Sc. Manage. $7(4)$ :
256-265. DOI: $10.3126 /$ ijssm.v7i4.32485
*Corresponding author
Aref Barkhordari,
Assistant Professor, Department of Political Thought.
University of Tehran, Iran
Email: arefbarkhordari @ ut.ac.ir
Peer reviewed under authority of IJSSM
(C) 2020 IJSSM, Permits unrestricted use under the
CC-By-NC license.
OPENQ ACCESS
This is an open access article \& it is licensed under a
Creative Commons Attribution Non-Commercial 4.0
(nternational
Keyw://creativecommons.org/licenses/by-nc/4.0/)

\begin{abstract}
The present paper with a focus on the analytic-historical method and the study of the works of Iran's Muslim philosophers in the Islamic periods is an explanation of the structure and nature of the political philosophy of Muslim philosophers in the Iran Islamic period. Political philosophy in the Islamic period of Iran is divided into two middle and new periods. The middle period starts from the arrival of Islam in Iran, and continues until the arrival of modern thought to Iran, i.e. the Constitutional Revolution. In this period, political philosophy has a tendency toward unity with religion and the rules of production of thought and political philosophy have been based on the domination of religious texts and the function of reason is simply summarized in the unambiguous explanation of the opinions of the ancients. The works of philosophers in this period are limited to the writings of the past, and gradually the tradition of margin writing becomes common. Typically, in this period, political philosophy becomes the guidance writing, diplomacy writing, tradition writing and at the same time adopts an authoritative commentary. In the new period of political philosophy, following the first period, it seeks to revive traditional concepts, and intellect and thought are seeking to be interpreted, with the difference that authoritarianism disappears. In other words, in the second period, in both fields of political philosophy and authoritarianism, we face a kind of void.
\end{abstract}

Keywords: Political Philosophy; Sharia Writing; Policy Writing; Authoritarianism

\section{Introduction}

A glance at various approaches of Iranian Muslim philosophers to political issues from Abu Nasr Farabi to Allameh Mohammad Hussein Naeini explains how political philosophy in the era of Ibn Sina leads to the development of theological issues and the unity of philosophy with mysticism in the position of coordination with religion and mysticism, and in the following periods, it approached to precept writing, Sharia Writing and Policy Writing, and it also clarifies that the playing with words and the explanation of some of the political structures engaged the minds and language of the Iranian philosophers in a course of nearly 800 years. Regardless of the events surrounding them, they are rehearsing and repeating the ideas of the past, and how the impoverished thought and authoritarianism in it forms the main pillars of their way of thinking and political philosophy, even the Constitutional Revolution in Iran could not prevail the intellectual recession and take the political thought out of traditional paradigm. 
Although the Constitutional Revolution could institutionalize its advantage by a delay of twenty years, Iranian thought never succeeded in attracting the intellectual and cultural ideas of modernity, and the voice of limited scholars who spoke of modernity did not echo. At the beginning of Iranian acquaintance with modern thoughts, the works that were presented by the first modern thinkers of Iran were unaccepted and in fact the Iranian world attached social and economic structures, and the process of modernization to traditional ideas before modernity, without any second thought. Even with the arrival of the intellectuals and the first modern thinkers of Iran, no changes have taken place in the system of thought of these people and no evolution appeared, and there are signs advices for the return of the Iranian-Eastern identity against modernity and the liberation of soul from the achievements of modernity. Thus, with the reflection on the thought of the second-era thinkers, we see that, in line with the first period of political philosophy in the second period, in addition to having a kind of neo-liberal approach, the authoritarianism of the first period was also eliminated in this period, and we are left with a kind of vacuum in the field of political philosophy as well as in the field of authoritarianism. Therefore, in the second period, the closed story, which was in conflict with the traditional political thought of Iran, has reoccupied Iranian thought in this period and according to Dariush Shayegan, has transformed it into the subject matter (Haghdar, 2003b:16).

\section{Political philosophy in the thought of Muslim philosophers in Iran Islamic period}

Political philosophy in Iran the Islamic period is divided into two periods: one, middle era and another, a new era.

\section{1- Middle Era}

The political philosophy in Islam and Iran (Iran Islamic era) was established by Farabi. He, who was familiar with both Greek philosophy and Islamic principles, wrote the first texts of political philosophy in Iranian-Islamic civilization to explain the political issues of his time. With the discussion of power, Farabi turned its agent from the kingPlatonic philosopher to the Islamic Imam and, based on the rational knowledge of the Greeks, founded a kind of metaphysical political philosophy in the breakdown of the earlier era. In the philosophical approach of al-Farabi, the dignity of the leader or, in other words, the Imam in society, is like the heart in the existence of human and like the relation of the first (God) to the universe, the existence of the society has existential precedence (And his existence has an existential precedent on the existence of society) (Haghdar, 2003:63). Farabi linked theology and politics in the unitary philosophical system, and generalized the results of the two. Farabi writes that the relation of the first to other creatures, is like the relation of the king to the other components (Tabatabaei, 1996a: 122), as in the creation, all beings have come to existence from the first being and through that system, the existence of City also depends on the existence of the first head and it's system is owed to him and the city has the order of the universe. Thus, in this case, the city is in such a way that its components are connected with each other and are in a hierarchical order, and the moderator of such a city is similar to the first one that the existence of other beings is related to Him (Farabi, 1995:117). Farabi, considering the combination of theology and politics, takes another important step, he first considers a kind of pyramidal hierarchy in natural beings, and then extends this order of hierarchy in the world of divinity and nature to the world of man and politics. Farabi points out that the creatures of the universe are many and, in spite of that, they are varied, that is why some are superior to some or lower than others. (Farabi, 1993:84). Farabi then emphasizes the similarity and unity of the structure of the universe and the human soul on one hand and the hierarchy of the components of Medina on the other, and he considers these three times the existence having a single ordinance. Farabi compares and unites the position of God, the heart and the ruler of city and writes:

As in human beings, the heart first becomes created, and then it causes the development of other organs of the body, the position of the head of the city is also that he must first establish himself, and then he also causes the formation and education of city and its components, acquiring the voluntary property of its components and its persons and order of their degree, and now the beings of the world are also the same, because the relation of the first to other creatures is such as the relation of king of the city, to other persons and its components. (Farabi, 1995:87). The most important result Farabi derives from these preliminaries in the field of philosophy is the division of Medina members into unequal components and the imposition of an authoritarian, hierarchical and componential order on the individuals of the city, which durability and consistency of each of them is due to the head of the city. In this order of authority, each component of city has a superior head, which nothing is superior to him. There are also people ruled that they do not rule over any other human being. Among these two, the absolute leader and the nobleman, there are other human beings who, although they are the heads of some, and they are under the control of some others (Ibid: 116-118). Farabi, therefore, prefers the head of city for the city and its people, and considering the difference between the power and nature of human relations, he considers the relationship between them to be an inalienable and authoritative relationship among maladaptive and complete human beings. (Feirahi, ed. www.feirahi.ir).

Farabi explains that most people require education and guidance, and thus somehow, they need another department, because humans are divided into several groups according to their ability to acquire knowledge and the 
ability to perform it in society. Most people can only imitate the knowledge of others. These people are obedient forever and in all cases. Others, while motivated by a teacher, employ the teachings of their chief scientist, and even give others the opportunity to do it. In Farabi's view, these people have a share of the presidency, and although they are under the rule of the first head, Farabi calls them the second head. But Farabi writes about the knowledge and position of the first chief: The first president, Ali al-Talaq, is someone who won't be ruled by others, and he has actual science and education, and in no way does he need any other man to guide him (Farabi1993: 77-78).

Farabi has thus established a wide authoritarianism in political philosophy, and when it combines philosophy and the law with each other in the Islamic society, in fact, the elements of authority and freedom in the philosopher's city spread to the relatives of Prophecy and Islamic politics. In his view, in a society governed by the tradition, there is, like the philosopher's city, the order of authority, only with the difference that the head of the Islamic community must be chosen by a faqih (Feirahi. www.feirahi.ir).

Farabi believes that the validity of the unity of reason and religion and the identical truth of philosophy and religion are the nature of the advices of the faqihs and the same philosopher, and the position of the faqihs in the Islamic society will be similar to the philosophers and thinkers in other societies (Feirahi. www.feirahi.ir).

Therefore, according to Farabi's words, the term "civilization" and the characteristics of the society and the characteristics of the leaders of the human community are said to indicate that, in addition to authoritarianism in Farabi's thought, he has been pursuing a philosophical view of civil philosophy and seeking a solution to the crisis of political affairs in dar al-Salam. Farabi, based on his ideas, established an independent approach to political affairs in the Islamic world and laid the foundations and principles of political philosophy which Muslim philosophers did not welcome. After Farabi, political thought did not encounter any significant intellectual and philosophical pursuit among philosophers, and, with the breakdown of the intellectual foundations, most philosophers turned their attention to theology and metaphysics issues related to the political philosophy, and by deviating from the truth of Farabi's political thoughts, led the philosophical approach in political thought to a recession. Some other philosophers who have met with a philosophical attitude toward social and political issues, have been evaluating and analyzing individual morals and stopping in explaining the foundations of political ethics (in the form of an individual), The divergence of the political thoughts of Muslim philosophers into ethics and the reliance on personal virtues in the administration of society has evolved in the work of Ameri and his contemporaries and subsequent scholars and eventually appeared in some kind of mutilated moralphilosophical declarations who were themselves a mixture of Greek thoughts And Iranshahri's opinions, which come to be religiously colored (Haghdar(B)2003:66).

Abolhassan Ameri, with the influence of Plato's philosophical thoughts in his writings like Farabi, has been devoted to explaining the philosophical branches of city and the way of social life of human beings, and devoted himself to discovering the social well-being of mankind, from the point of view of the integrity and fulfillment of happiness in society, The approach to tradition is the same as the perfection and virtue presented in the philosophy of the Greeks (Ibid: 67). Ameri believed in the separation between religion and politics while they were connected, and believed in the true prophet and the kingdom of righteous, a divine blessing, which in some verses that distinctly versified Prophets and kings, the reason for the unique gift of Two persons or two officials are entrusted with each and every one has their highest rank. The link between religion and politics, in Ameri's viewpoint, is based on faqih rulings, but on the other hand, he interprets Iranshahri of religion, which suggests his interest in the idea of an ideal kingdom of ancient Iranians. Like Ameri, Iranian diplomacy writers put the king at the head of the political pyramid and they consider the salvation and misleading of society depending on his wisdom or unknowingness. A commentary that Ameri offers for religion mainly focuses on its ethical aspect and takes on the part of Iranshahri.

Paying attention to the ethical aspects of religious beliefs and the emphasis on unity, has led Ameri to put human moral reform ahead of his civil reform. Ameri's statement in Al-'Alam B'monaqb 'al-Islam indicates that he is distancing himself from the Greek philosophy and approaches the thought of Iranshahri, in such a way as to bring moral reform to the fore.

Meskouye Razi elaborates on political issues based on ethics derived from philosophical science, and after discussing the voluntary actions of man he attains the social activity. In his works, Meskouye attempts to present a philosophical interpretation of religion, based on which the social reception of morality in the political arena and the family presents, in the sense that politics is the same as the divine law and the tradition of its justice, which is responsible for the provision of public expediency and salvation of humans in the world and the Hereafter.

In completing his theory, Ibn Meskouye confronts Aristotle's rule with a religious leadership and emphasizes with the religious color of worldly rule: Imam, the ruler of justice, works in the maintenance of equality as the successor to the owner of the sharia. From Meskouye's point of view, religion and king are twin brothers and they are not separated, therefore, the religion is the base and the king is the protector. Meskouye continues to relate Imam 
(leader) with the status and considers it to be the type of relationship between father and son and brother with brother (Ibid: 69).

Therefore, as it can be seen Ameri's and Meskouye's words, political thought is transmitted to social ethics among Muslim philosophers, and some of them attempt to elaborate the moral principles of morality and provide instructions for the health of the community and in addition to any text and any great philosophical work in the Islamic world, there is no authoritarianism in it.

Ibn Sina deals with a different attitude from a moral point of view to political thought and discusses it from a philosophical point of view, in relation to religious beliefs. Politics, which is a small part of Ibn Sina's philosophical poetry, stands as an expression of the status of lawmaking and its role is for the well-being of society, which is the highest example of social law and its maker is a prophet. In this sense, the return to the Greeks' political views through Farabi in the explanation of religion is a tangible expression of the theory of the king's philosopher in Ibn Sina's thought (Ibid: 69).

In this way, Ibn Sina puts political discussion under the prophetic discussions, which is also one of theological topics, and transforms political thought into Islamic philosophy into a sub-stream, which ultimately transforms with the growth of divine issues and the unity of philosophy with mysticism in the eyes of the next philosophers. Political thought goes far beyond the philosophical issues and political philosophy leads to a non-aligned position. In this regard, from Ibn Sina to Mulla Sadra, the political ideas are neglected and philosophers are subjected to the rational explanation of religious advices. In addition to the aforementioned issues, Ibn Sina offers a tradition of anthropology and political order, which typically has an authoritative structure. He considers the difference between the intellects and natures and also believes that the sociopolitical levels of human beings is normal and in accordance with the guidance of Allah Almighty. He writes:

God blessed the people with his grace and mercy and created them unequally in their thoughts and intellects, as they differed in property, homes and social ranks. Therefore, the owners of reason and thought know that whenever all the people were king, they destroyed each other, and if they were all servants, they would completely destroy themselves (Feirahi.ir).

On this basis, Ibn Sina considers rulers the supreme and most worthy people in learning wisdom and politics to guide the world. Then he mentions the hierarchy of peoples from the highest to the lowest (Al-masal Fel-mesal), and emphasizes that every single human being, while they are ruled, have their own a supremacy. He adds that the circle of hegemony of each is as large as the range of powers that were placed in their nature (Feirahi, feirahi.ir).

About the authority of the city, when it links politics to the prophetic debate, it spreads authoritarianism in IslamicPlatonic philosophy to the field of scholarly knowledge and political figh. In view of the fact that the human community and the life in a city, as other natural phenomena, can be seen in ways that are prone to evil entering into divine laws, the way of creation, and the distinction and differentiation of human beings in city are from the source of divine affection. Thus, he determines the necessity of prophecy and sharia. The most important and first objective of the Sharia and the covenant in the eyes of Ibn Sina, is the status of the traditions and order of city based on the three components, rulers, business and guardians, as well as the order of the authority and hierarchy of each of the executions and based on triple goods from excellent to lowbred. Ibn Sina writes in healing theology: "Therefore, it is imperative that the first law-governed intention and duty of the legislator in the establishment of the traditions and order of city on the execution of the tripartite, rulers, guardians, in each component they also have a chairman, He has also arranged a hierarchy of orders from the highest to the lowest. (Ibn Sina 1404 AH: 435. 1377.S :310).

However, the questions and perceptions that Muslim philosophers have about the nature of political power within a system of philosophical thought are of great importance to the history of Islamic thought. By linking their philosophical system with Islamic theology, they have placed religious thought, especially in the realms of man and politics, at the dead end of their authoritarianism their ruling philosophical system. Islamic philosophy expanded the interpretation of Islamic texts by extending the basic concepts of Islamic revelation, divine affection, and prophecy, on the basis of our metaphysical, anthropological, and Platonic city, which in fact, authoritarianism is was more a special rebate of Greek philosophy than that derived from religious doctrines.

Among other prominent thinkers in Iran and Islam is Khajeh Nezam al-Mulk. He is the author of the policy book. Khajeh assigns the entire book to the kingdom and monarchy. The basis of Khajeh Nezam al-Mulk's theory in the first chapter of the book is expressed in the context of the people and the movement of the time and God of the universe. The basis of the theory of politics is based on the ideals of utopia thought. According to this theory, the chosen king of God is the owner of king's glory, and this is the ideal king of the Sharia and not its executor (Tabatabaii (B) 1996: 131). The first feature of such king is the justice, which is itself a subordinate to the king's glory. Therefore, order and security exist until there is a king who is fair and honest and rules with glory. In the eighth chapter, Khajeh considered 
the king as the king of glory, and extended the utopia theory to some of the Iranian rulers and kings of the Islamic era.

In Khajeh's theory of utopia, the ideal king, is himself a creditor of the Sharia, and an ideal kingdom will be realized when the power of the government is in harmony with religion and wisdom. The diplomacy writing realizes the sultan with two traditions which it has imposed on him: the sultan who is sitting on the throne in the Islamic era. Such a royal one must have a king glory, and on the other hand, praying and pilgrimage, fasting and alms are consistent of his character.

At the end of Khajeh Nezam al-Mulk's discussion, it can be said that Khajeh was the first great representative writer of the Islamic period of Iran. He laid the foundations of a new political thought and gathered elements of utopia idealism with the political realism of the Islamic period of Iran. What is important in this action is his successful attempt to break with the political thought of the rulers and the sharia writings. In this regard, it can be said that Khajeh Nezam alMulk guided the development of political thought in Iran, which he had prepared by returning to Iran's political ideology. But the idealistic attitude of Khajeh's political thought gradually disappeared in practice against his political realism, and the mainstream of the political thought of politics fell on the path to the absolute monarchy. However, by writing a policy based on the experience of the thirty years of the ministry and receiving from the tradition of Iran's political thought, he developed the theory of absolute monarchy and the central political system that, for nearly a thousand years, until the preparations for the constitutional movement, was The foundation of any system and theory of government in Iran (ibid:61).

Another thinker of Iran is Khajeh Nasir al-Din Tusi. He was a good commentator for Farabi's political philosophy, and as well, in the field of political science had special theories. He presents the theory of Shiite Imamate system in the form of philosophical-theological issues as a system that provides grounds for human development and perfection. Khajeh Nasir's political thinking deals with the universal interpretation that makes it purposeful and mankind is a perfectionist, and considers politics as a divine policy that gives them human treasures and virtues. Such a policy is conceived and implemented only in Imamate system. Khajeh Nasir has established his practical and civil philosophy on theoretical philosophy, and there is a direct relation between all should and shouldn't, and in this regard, what in practical terms to personal and social values and goodness and virtues seems rational, is related to knowledge that the divine wisdom receives in its theoretical form through intelligence and the source of revelation and makes them practical for themselves and others.

Khajeh Nasir imagined political management in both theoretical and practical aspects, and based on the theoretical dimension, he considered the practical dimension as the result. By designing and rejecting the natural policy approach, in his own words, he unqualified, sought to provide a supreme and balanced political management based on the humanitarian approach and, in his words, he completed it. He looked at human being with a monotheistic viewpoint, and by recognizing the origin and purpose of human, according to this view, he found his basic needs and considered the government or the practical form of politics to fulfill it to perform special tasks.

In addition to the above issues, which indicate that Khajeh's view is more sharia tended and has little relation to political philosophy, these discussions represent a kind of authoritarianism in his theory, inasmuch as he, in his comments, in the political and social circles (Imam) Is the head of community pyramid, and Imam is the wise, the Distinguished, the able and the Prophet Ali, and in his view the sign of Malik Ali were four things: Wisdom, reason, persuasion and imagination, and fourth, the strength of jihad, and points his presidency based on wisdom. (Khajeh Nasir al-Din Tusi1998:287).

Another one of Islamic and Iranian philosophers is Mulla Sadra. He is the greatest philosopher in the 11th century AH in Iran and culminated in the philosophy of revelation. Mulla Sadra was a descendant legacy created by a combination of Sharia and Sufism. He was considered to be the last hereditary idol of the intellectual thought of the Islamic era, against a contradictory and dualistic situation; on the other hand, he inevitably relied on the combination of Sharia, Sufism and Greek thoughts, and in other words, he realized that the purely religious interpretation of Sharia, which has been established in Iran in the course of time, is not consistent with the essence of wise reception of the Sharia. Thus, Mulla Sadra, in this contradictory state, relied on real mysticism with degenerate Sufism and Angularity, and based on the inner perception of Sharia with the Zahir (exterior layers and perspectives) Sharia, sought to fight, without knowing that the truth of the spirit of time had needed a transformer philosophical thought. He also failed to create a fundamental change in Iranian philosophy and set up a new plan that would be the basis for stability for the new era of Iranian history.

In the realm of political thought of Mulla Sadra, it is only important from the point of view of its breakdown and its disintegration. He, who made all his efforts to prove physical resurrection, was unaware of the reflection on human livelihoods. Only once in the final section of the book of origin and resurrection, in accordance with the final section of the book of the healing theology of Ibn Sina, he summarized politics in which politics and prophecy were presented with a view to Plato's New Platonist interpretation, But it is interesting to note that, despite the parallels between Mulla Sadra's discussion with Ibn Sina's 
words and the places which these two discussions are in the philosophical poem of the two philosophers, Mulla Sadra contributed to the discussion of the nature and types of city in the discussion of the chairmanship of Farabi's issues. The people of utopia city and especially al-fosul al-Madani are mentioned appropriately, without saying anything new.

With the passing of Mulla Sadra, there was no important change in the philosophical and political thought, but a period began to which lasted for nearly three centuries, that is, until the preparations for the constitutional movement in Iran and even beyond, and that's how marginalization and fidelity became commonplace. And so, the worst striking blow to the body of intellectual thought in Iran.

Mirza Mohammad Hussein Naini is the last representative of the traditional and gravitation of the emergence of modern political thought in contemporary Iran. He correctly understood that with the traditional concepts, the constitutional theory and the new political system in Iran cannot be explained, for this reason, by relying on the thoughts of the intellectuals of the Constitutional era and modern thoughts, he sought to explore the constitutional system (Barkhordari 2016: 6957). (Works by Mirza Fath Ali Akhundzadeh and Mirza Malekm Khan, etc. are texts that have spoken about political affairs in breaking the intellectual and traditional approaches and based on the foundations of modern thought in Iranian culture) (Barkhordari 2020: 58-62) The pamphlet of Tanbihe Alomeh and Tanzieh Almeleh, written by Mohammad Hossein Naeini, are important in designing new concepts of the political and traditional themes and placing the circle of communication in the system of thought between the two old and new spheres. The Tanbihe Alameh is in the sense of informing the nation about the necessities of Sharia and the retribution of Allah means to eradicate the tyrannical innovation. Proving of the necessity of the reign is the next action of Naeini. In his book, when discussing the truth of the monarchy, he spoke of the necessity of limitation, because the monarchy is a type of imamate and the observance of the rules of trusteeship is a hypothesis. He says that the monarchy is a necessity for the endurance of the world system and for the subsistence of mankind, and he is referring to the reign of the state, which he perceives as either right or, formed from the wrath, and ultimately, he considers the method of gaining power either ferocious or Arising from a system of inheritance or choice. In his view, the monarchy has two duties: 1. internal systems. 2. Preventing the intervention of foreigners (Barkhordari 2020: 63-64). Naeini continues to write these two duties as political rulings, which is the second element of practical wisdom. He explains two types of politics to explain his purpose. The first type is despotic politics, which is interpreted as dictatorship, domination, tyranny, cruelty, and so on, in which the tyrant considers the people and the country as his own property, and the second type of politics is based on the right, trust and fairness that can be limited by the area, the constitution and the justice, that is, totally based on the command and law. (Qaderi, 2000: 230). Referring to historical events, Naeini described the phenomenon of tyranny in the history of Muslims, and then, relying on Shiite fiqhand rational methods, he mentions the need to change the situation from the monarchy to the constitutional or limited.

\section{2- Contemporary Era}

In this period, a movement was formed which, as an intellectual approach, transposed anti-Western ideas with the mystical and indigenous teachings of Iran, replaced the post intellectual movements and left intellectuals from the main content. The most prominent components of this trend were ideology, game politics, anti-Westernize, false nativism and the spirituality, which on the one hand was promoted by people like the elite and the other from politics, and on the other side it came to anti-West ideas of Ahmad Fardid. In the continuation of this turbulent flow of currents to religious intellectuals appeared, some like Mahdi Bazargan and journalists such as Al Ahmad and academics who have suffered from modernity such as Ehsan Naraghi in the 30s to the 50's. (Haghdar, 2003a:14).

In the middle of this period of cultural life in Iran, we have other people, such as Dariush Shayegan, Seyyed Hossein Nasr and Ahmad Fardid, who have focused on philosophical issues in the new era. As we will explain, in this period of philosophy, in addition to losing its character, its authoritarian nature also disappears.

Hossein Nasr is one of the thinkers of this era. In his philosophical journey, he continued to think of the revival of Islamic philosophy. From his point of view, Islamic philosophy is a great sea of intellectual and rational traditions, which arose from the merging of the religion of Islam and the philosophical thinking of ancient Greece and Persia, and had a profound effect on European and Indian philosophy and mysticism (Nasr, 2003:217).

Philosophy of research in Nasr's intellectual process is a search for God's perception of a high degree of excellence, and philosophy is considered as a sacred endeavor that ultimately leads to immortal wisdom. Therefore, philosophy becomes an attempt to become knowledgeable in divine wisdom, or in the wake of Nasr's "metaphysical wisdom." In the intellectual and philosophical project of Nasr, wisdom, he observes the philosophical tradition begun with the teachings of the Eris the Prophet and Hermes, and this tradition was passed on to subsequent generations in different civilizations, the wisdom that crystallizes in the philosophical system of Nasr as Real wisdom is obtained in the light of the Qur'an, Hadith and tradition, and based on rational intuition. 
Nasr strictly defends the divine wisdom and says: "Our intention is to introduce the traditional metaphysics of Islamic philosophy into a new world, and notes that in the teaching of philosophy, Islamic philosophy should be the main axis, and other schools of philosophy should be taught in connection with it. (Nasr, 2004:49).

The ontology is holy and transcendental in Nasr's view. To him, the ultimate existence of God is of a comprehensive nature. Whether the matter discussed by a philosopheris analysis of art or science, the philosopher finally speaks about him.

In general, Nasr's goal is of discussing the ontology is the rejection, and denial of rationalized and rationalism. He considers the intellectual foundations of the ontology debate of the meaning and concept of Islamic philosophy and sees it as the only absolute truth. The meaning and concept of Islamic philosophy is in the light of Qur'an and Hadith, in which the term wisdom is used for both of them.

According to Nasr, Islamic philosophy is itself a philosophy based on revelation and includes a worldview in which the significance of revelation in the great and small world has a fundamental contribution, and in Islam, the revelationbased philosophy is ultimately perfected and expanded and developed (Nasr, 2003:183).

By emphasizing Iran's contribution to Islamic philosophy, Nasr emphasizes that our knowledge of understanding of the intellectual-philosophical tradition is not only a school and academic issue, but also a matter of our future life, as a result, we must know where we are a, where we want to go and all this is subjected to know our past. Nasr's goal of recognizing the intellectual-philosophical descent was to confront the West, so Nasr resorted to a mystical, god knowing interpretation of Islam in order to emancipate this Western exile, claiming that Sufism was the central axis of his thinking and worldview. He turned away from rationalism for the benefit of Ishraq, and also from a Cartesian idea to the revelation, and formed a new science to the benefit of traditional metaphysics. Nasr criticized the entire civilization of the modern age, the superiority of the mind over the body and spirit, the mystical discard, the removal of the divine essence of nature, and the supporters of non-religious science and knowledge as a way of universal social salvation.

Finally, we can say that Nasr is the representative of a generation of traditional thinkers of religious beliefs who did not want to surrender to the idea of modernity and secularism. He demonstrated that the traditional culture of Iran had not been breathless, and helped to strengthen the native language's philosophical armor. In addition, he believed that non-Western cultures had never lost the battle of history to Western civilization (because Western civilization was inflicted by a fatal illness), he instilled some optimism and pride in the philosophical veins of the Islamic community.

Dariush Shayegan is one of the other thinkers of this period. In analyzing his ideas of dialogue with the project of spirituality and wisdom against ideology, nativism the ideas of modernity, formed a kind of self-assessment and westernism. Shayegan is one of the few Iranian intellectuals who are interested in both Western philosophy and Asian philosophy. He is not in the Western Spectrum, nor is traditionalism dominant in his thoughts. This look also stems from modern learning, in the light of global awareness that is rapidly evolving.

Shayegan seeks for new developments in the pursuit of harmony between the modern West and the traditional East, because he is aware that these advances are responding to different areas of human life. On the other hand, it pushes the traditional spirituality to the present, because it is concerned about the loss of a predetermined identity of the traditional world and the presence of the new world with the same identities. Shayegan, in harmony between the modern West and the traditional East, uses words that are worthy of interest and more to value the two old and new worlds, and before the precise and logical design of the problem, modern civilization with concepts and categories such as violence, Nihilism has put a traditional world in peace and tranquility.

In discussing the cultural identity of the East and the eternal memory of the traditional era, Shayegan mentions it to be against the emergence of Western and European Nihilism. According to Shayegan, this vision reflects the declining trend of Western thought, a rigorous, intuitive way to technical world-view, from the end-of-the-world and the resurrection to historicism, which form the course of the thinking of Asian civilizations. On this basis, according to the Shayegan, about the civilizations of Asia, they are in their present state (Shayegan, 1992a:3). In the early years of his thinking, Shayegan tried to solve the problem of the traditions of the heritage and the fragmentation of its nature, and to cope with the encounters of these civilizations with modernity, because in his view, with all our efforts to preserve our cultural identity, our ethnic memory is about to die. In such a situation, the discussion about the necessity or unnecessary nature of the traditions, identity, etc., without a radical discussion of the conflicting forces, is superficial, and until this discussion takes place and we do not know or understand the existence of ourselves and the civilization that we are known to be. Questioning means the adoption of philosophical thinking, and it's only by this method that we can understand the nature of Western thinking and our own identity. According to Shayegan, our traditional way of thinking, developed in the context of the religion of Islam, and we cannot raise this question, and if such a question is posed, it is the loyal origin of the 
inspiration that it is a revelation which gives the answer before the question becomes available, but He would not stay loyal and would divert his path. (Ibid: 4).

Therefore, the only way of confronting tradition and modernity, as Shayegan recognizes, is through philosophical thought that is based on the passage from the era of wisdom and would let the way of philosophical thought in that era (philosophy of history) be available to men, This issue goes some way beyond the previous thought, and in the Shayegan intellectual thought it becomes one of the real points of thought about the fate of ancient civilizations with the advent of modern civilization. The idea of issue of the historical appreciation of Asian civilizations is a philosophical issue, and the method of questioning it is Western (Ibid: 5).

Shayegan explains the period in which the historic destiny of ancient civilizations faces modernity. He believes that the double illusion, which is the birth of two suspicions, manifests itself in two negative aspects of Westernization and alienation, and creates a period of entanglement. That period is contemporary with alienation. Because our passion for the West and our mental parallelism against its astonishing products, is a reminder that we require our traditional thinking which, in the words of the Islamic theologians, has been a source of concern for the prophecy. Therefore, our way is closed to the center of Western thought, as the focus of the manifestations is on the ethnic memory, and our historical destiny is that we have neither this nor that. (Ibid: 82).

Shayegan was trying to link modernity with tradition. For him, the past was still in such close proximity, even if it had been deposited to the ground, it could still be taken out of the grave. How? With the non-historical metaphysics of substance or essence that connects the mythical world of the Orient with the rational world of Western thought. He thought of Henry Carbon, a man who was fully committed to mystical thinking, who was able to do this journey by flicking the door between Suhrawardi in the twelfth century of Iran and Haidger of the twentieth century of the West. In addition, Shayegan believes that traditional Asian societies are lagging behind the West, and this situation has recently become their problem.

Another thinker of this era is Ahmad Fardid. As a philosopher, he introduced the concept of Westernization in Persian. With the concept of westernization, he sought to describe our historical situation as a Western-dominated or self-alienated people, and also, he wanted to mean the whole of world history from a philosophical point of view by following Heidegger (Barkhordari2019:10). The most fundamental letter of Fardid, based on all the divine wisdom and philosophy of his history, is derived from the Arabic theory of al-asma Mohya al-din, the historical appearance of the name of Allah in the world of martyrdom. In theoretical mysticism of Ibn Arabi, the names are the rational constants or the nature of objects that are found in divine science in the unseen world, and then, according to divine appreciation, it appears in the form of objects in the sensible world. In this mystical view, every nominal is one of the names of Allah. The theory of the historical appearance of the name in Ibn Arabi's theoretical mysticism is not unlike the theory of historical extension of the idea in Hegel's philosophy, at least in appearance. Although Fardid is a follower of Heidegger and does not pay much respect to Hegel; however, under the influence of modern-day historiography, this theory brings the appearance of the names to the world history, and then blends it with Heidegger's critique of the history of Western thought as metaphysical history. This is the issue of al-'Asma's knowledge which Fardid accepts from Ibn Arabi and states in his own language: a problem that is not in our day at all, is the problem of names and that is anti-tyranny (Ashuori2004:8).

Fardid brings this science of al-Asma into a historical universal world and, by his division of world history, sees it as a name for each era, which, in his view, is the same as the appearance of the Almighty God (Allah). This combination of Ibn Arabi and Hegel, then Heidegger, attached his theory of metaphysical history. And in this midst, two concepts of matter and form are added to Aristotle's nature. Fardid also brings these concepts to this philosophy of history. As the archetypal relationship between matter and form, which Aristotle brings to the natural world to determine the changes, he brings them to the realm of history, and states that, with the transformation of the earlier historical form, the name of that history is converted to the form and the face of the old name. With the advent of the West and its modern historical form, the name of humanity, Eastern part and its history, and the name that symbolized the East and its history, begins to be the subject of the history of Westernization of the East. In Ibn Arabi's puzzle, along with Hegel's philosophy of history, and the form and material of Aristotle, one more thing should be added and that is the Heidegger's history of existence, and his recognition of the history of Western thought as metaphysical history or the history of fall of truth. Accordingly, historical and civilized forms, in Fardid's language, are the forms of the emergence of existence and the problems. Philosophy of Fardid's History is thus a mixture of the mythological Sufi interpretation of the creation of Adam and the teaching of the names to him, with Muhiyeddin Arabi, the other concept of universal history, Which Hegel's philosophical message ultimately conceived the concept of the existence of the realities and the history of metaphysical thought as the date of the fall of truth (Ibid: 11).

\section{Conclusion}


Farabi set up an independent approach to political affairs in the Muslim world, and he had founded a political philosophy with the principles along with authoritarianism that, after him, Muslim philosophers did not appreciate the welcome. After Farabi, his political thought has not been followed up with considerable rationalism among philosophers, and during this period, the importance of reason is summed up in an inexplicable explanation of the views of the ancients. In this period, political philosophy begins its work in unity with religion, and in relation to the political philosophy of the Greeks, it leaves its main channel, and by breaking away from its intellectual foundations, most philosophers focus their attention on theological and metaphysical issues (but with Preserving the authoritarianism in it) in general philosophy, and by deviating from the truth of Farabi's political thoughts, the philosophical approach in political thought was put to a recession. Some other philosophers who have a philosophical attitude toward social and political issues have found themselves in the process of evaluating and analyzing individual morals and stopped explaining the philosophical foundations of political morality (in the form of an individual), And ultimately appeared in a kind of morally-philosophical advice that was a mixture of Greek and utopia ideas and religious colors. In this regard, after Farabi, an indifferent political thought and philosophers are subjected to the rational explanation of religious doctrines, and political thought goes far beyond the philosophical issues and political philosophy leads to a non-aligned position and some kind of advice writing, sharia and diplomacy writing will be replaced and during this period, the political philosophy preserved authoritarianism in that form and nature, which continued until the Constitutional Revolution in Iran. After the Constitutional Revolution in Iran, it took several decades that the Iranian elites, with a critical reflection on their traditional heritage, understood the real difference of the modern world with regard to the new concepts in which they formed into the traditional world and reached to a realistic believe of political ideas of modernity. But as previously stated, after the Constitutional Revolution, Iranian thought never succeeded in attracting the intellectual and cultural ideas of modernity, and the voices of the few thinkers who spoke about modernity did not reflect, and no change took place in the system of thoughts, and in fact, we witnessed the notion And advocating for the return of the Iranian and eastern identity, and according to the famous renaissance of modernity and the liberation of the soul from the achievements of modernity, as we have been examining in the thinkers' way of thinking such as Nasr, Shayegan and Fardid, The traditional Iranian politics have been resurrected in accordance with the thought of its new era, in addition to this, authoritarianism has already been eliminated in traditional political thought of this era.

\section{Acknowledgement}

This study is not supported by any particular institution or individual and the author of the article was personally responsible for all costs of this research.

\section{References}

Ashuori D (2004) Jostar Journal. 23 February.
http://ashouri.malakut.org/wp-
content/uploads/2014/03/Fardid.pdf.

Barkhordari A (2019) the Influence of Continental and Analytic Philosophy on the New Thinking of Iran. Advances in Social Sciences Research Journal 6(3): (10-18). DOI: 10.14738/assrj.63.6171

Barkhordari A (2020) Systematization and the Model of Political Management in Contemporary Iranian Thinker's Idea. Journal of Social Science Studies 7(2): (57-71) DOI: 10.5296/jse.v7i2.16937.

Barkhordari A (2016) The Evolution of Iran's Contemporary Political Thought with Emphasis on the Problem of Modernity. The Social Sciences 11(29): (6954-6962) DOI: 10.36478/sscience.2016.6954.6962

Farabi AN (1993) Al-Siyasah Al-Madinah. Fuzzy-MeterI Najar Research. Beirut. Dar al-Mashhad.

Farabi AN (1995) the opinions of the people of Utopia and its contradictions. Ali Abolmahm Research. Beirut: Dar alHilal.

Firahi. D (1999) Theoretical Problems of the Freedom Plan in Islamic Thought. Journal of Political Science. Qom 7(4): (25-35)

Firahi D Theoretical Problems of the Freedom Plan in Islamic Thought. www.feirahi.ir.

Ghaderi H (2000) Political Thought in Islam and Iran. Tehran. Samt Publications.

Haghdar A (2003a) Shayegan and the Crisis of Traditional Spirituality. Tehran. Kavir Publications.

Haghdar A (2003b) Political Power in Iranian Thought. Tehran. Kavir Publications.

Ibn Sina (1998) Theology of Healing. Qom. Maraashi Najafi Library. 1404 AH. Also Theology of Salvation. Translated by Seyyed Yahya Yasrabi. Tehran. Fekre Rouz Publications.

Nasir Alddin TK (1998) Naseri Ethics. Minoo and Heidari Correction. Tehran. Kharazmi Publications.

Nasr SH (2003) Eternal wisdom (Javdane kherad). Tehran. Soroush Publications.

Nasr SH (2004) Islamic rational tradition in Iran. Tehran. Ghasideh Sara Publications.

Shayegan D (1992a) Asia against the West. Tehran. Amir Kabir Publications.

Shayegan D (1992b) The New Enchantment: Forty-piece Identity and Mobile Thinking. Tehran. Agah Publications. 
Shayegan D (1992c) The Spiritual Thinking in Iranian Islam (Henry Corbin). Tehran Publications.

Tabatabaei J (1988) A Philosophical Introduction to the History of Political Thought in Iran. Tehran. Islamic Culture Publishing.

Tabatabaei J (1996a) The Decadence of Political Thought in Iran. Tehran. Kavir Publications.
Tabatabaei J (1996b) Khawaja Nizam al-Molk. Tehran. New Design Publications.

Tabatabaei J (2007) An Introduction to the Theory of Decadence in Iran. Tehran. Contemporary View Publications.

Tabatabaei J (2007) Tabriz school and the foundations of modernism. Tehran. Sotoudeh Publications. 